\title{
Performance Measures for Student Assistants
}

\section{Jane McGurn Kathman and Michael D. Kathman}

\begin{abstract}
This article discusses the importance of establishing and using performance measures with student employees in academic libraries. These measures set expectations for performance and become management tools to motivate, evaluate, and reward student employees as well as to improve student commitment and provide a sense of accomplishment in student jobs. Drawing upon management literature dealing with full-time employees, the authors modify that work to fit student employees' unique needs, specifically the fact that students are part-time and are not necessarily motivated by the work itself.
\end{abstract}

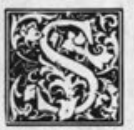

tudent assistants are essential personnel in the academic library; the efficiency and effectiveness of library operations depend to a large extent on this resource. Even though their value is well-known, little thought may be given to managing student assistants. Management theory and practice used with full-time employees may be absent in relation to these part-time employees. The establishment of performance measures is an important aspect of management practice and should be used with student employment. These measures set expectations for performance and become management tools to motivate, evaluate, and reward student employees as well as to improve student commitment and sense of accomplishment.

Though performance measures are important management tools, literature on student employees fails to consider them directly. Evaluation procedures are covered in the literature, and some work has been done on how long it takes to do specific tasks, e.g., the number of books that can be shelved in an hour. The literature, however, does not deal with overall student employee performance measures. In CLIP Note \#7, Managing Student Workers in College Libraries, we provided some examples of job descriptions and evaluation forms, but none of the libraries we surveyed documented performance measures. ${ }^{1}$ This article expands on what we presented in CLIP Note \#7 so that managers might incorporate this theory into their student employee programs.

Some of the body of literature on performance measures that exists for fulltime employees is appropriate for student employees and some is not. We will attempt to modify the work done for fulltime employees to fit the unique and different needs of student employees, specifically their part-time nature and the fact that they are not necessarily motivated by the work itself. ${ }^{2}$

There are many definitions of performance measures. For the purpose of this article we will use the following as a beginning point. A performance measure

Jane McGurn Kathman is Associate Professor in the Management Department of the College of Saint Benedict, St. Joseph, Minnesota 56374, and Michael D. Kathman is Director of Libraries, Media and Academic Computing at St. John's University, Collegeville, Minnesota 56321. 
is "a statement of how well the employee is expected to achieve each of the primary responsibilities in the job description. It is the standard against which his or her performance will be measured. It sets the par for the course so the employee knows at all times how he or she is progressing toward expectations." ${ }^{3}$ Having defined performance measures, we will now look at why they are necessary, what measures are appropriate, and how to establish measures for individual student employee jobs.

\section{NECESSITY FOR PERFORMANCE MEASURES}

Why are performance measures necessary for student assistants, given the nature of student employees in our libraries? Planning the work and monitoring performance are crucial managerial tasks. Students usually work a maximum of ten hours per week and in effect share jobs in the library. Therefore, eight students may do the work of two full-time workers. Performance measures assist managers in planning and monitoring activities. ${ }^{4}$ Coordinating the students' work by the use of hourly, daily, or weekly performance measures can enable the students to know what is expected of them and decrease the need for constant supervision while improving the quality and quantity of their work.

James Evered has observed that "every employee is entitled to know exactly what he or she is expected to do, how well it needs to be done, and how performance compares against the standards for the job." ${ }^{1}$ Having a set of performance measures for jobs students are expected to perform will increase the efficiency and effectiveness of utilizing student employees in the library. Such standards should be clearly communicated to students during their initial training period and referred to frequently thereafter. By doing so, supervisors communicate the importance of the work, increase student commitment to a particular quality of work, and provide an ongoing evaluation tool for student supervisors.

"Performance standards provide beforethe-fact challenge and commitment, during- the-fact monitoring and control, and after-the-fact review and appraisal," asserted Robert F. Smith and Kerry Tucker. ${ }^{6}$ Performance measures represent objectives of a particular job and expectations for employee perfor-mance in order to achieve the responsibilities of the job. Generally, supervisors already have measures of performance for their employees. These performance measures may not be in writing, but most supervisors have thought about what they expect of student assistants and are upset when students do not meet these expectations.? Intuitive performance measures are, however, not sufficient. Supervisors need to have written measures based on data. If supervisors do not record and communicate written standards to employees, they are neglecting an important managerial task and may not get the work done to their satisfaction.

\section{APPROPRIATE MEASURES}

What is an appropriate standard of performance? Mary Ann Joyce offers, "It's many things: one that accurately and completely measures the right things, with the right emphasis; one that's flexible; one that works for the organization, a standard that the current work force can reasonably meet; and one that can be administered equitably and efficiently." ${ }^{\prime 8}$ Measuring the right things means that librarians are attentive to the results expected, not the task needed to attain the results. Shelving books is a task; shelving books in the correct order is a result. The right emphasis means that we may need to weigh some results more heavily than others for a particular job. For example, we may weigh the accuracy of shelving books more heavily than the quantity of books shelved.

Sometimes there is a need for a flexible standard. When something in the environment changes that affects the nature of the work-uneven work flow beyond anyone's control or radical change in the nature of a given job-a standard may have to be changed. An example of uneven work flow might occur in processing materials. Although it may be desirable to have a relatively 
consistent flow of materials coming into the processing area each day, there are times of the year and external events that may make that impossible. Shipping strikes, year-end mass ordering, institution-required moratoriums on ordering, or other such events may make it necessary to change the performance measures for a particular job or jobs. Student employees assigned to processing will need to have other responsibilities if there are no materials to process. Conversely, if there is a large backlog in processing, other employees may need to assist in this task. This need for flexibility should be communicated in the job description and in the performance measures for particular jobs.

An example of the second need for a flexible work standard might be the impact of automation on certain jobs in the library. Implementing automation in circulation may drastically alter the standard of performance for student employees in that department. The ability to wand in a bar code makes it unnecessary to check for the correct book card in the pocket and eliminates the need to file book cards accurately. The circulation student employee must now make certain that the light pen reads the book bar code and the patron bar code. The student employee must know what to do if there is no bar code on the book and what to do if the patron ID is not valid or does not read properly. In this case the supervisor will have to review the student position completely and establish new performance measures.

The unique culture and work ethic of any academic library should be reflected in the performance measures for student assistants. Included in this consideration of culture and work ethic should be the mission of the institution, the nature of the student body, and the library goals. Different institutions put different priorities on various tasks. At some institutions picking up the books left on tables and having few books in the "to be shelved" area is of primary importance. As a result, student employees are temporarily shifted from other responsibilities to this task as a matter of priority. In other libraries the rapid processing of materials is of prime importance. Again, students may be shifted from other responsibilities if for one reason or another a backlog occurs in the processing area. These priorities should be made clear in the performance measures.

How are performance measures determined? To set performance measures, one needs to start with a job analysis for each job student employees are expected to perform. A job analysis begins with describing the tasks, duties, and responsibilities associated with each job and then identifies the critical elements. ${ }^{9}$ The results desired from the performance of the job are the critical elements. From this analysis one should be able to write a job description that emphasizes "responsibilities of the job, not the activities of the job." ${ }^{10}$ For example, a student working in cataloging may have an activity of labeling books, but the responsibility is to label the books accurately. The delivery of mail is a task, but the timely delivery of mail is a responsibility. Outlining job responsibilities is the firststep in establishing performance measures.

The next step is to determine satisfactory levels of performance for each important job element. In developing performance measures, select any one of the responsibilities in a job description and complete this sentence regarding the particular responsibility: "I will be completely satisfied with your work when. . . ."11 For a student shelving books, the performance measure could be to shelve fifty books accurately within an hour. Smith and Tucker stated, "Standards should be specific and quantifiable, hinging on hard-data answers to questions such as: How much? By what time? At what cost? Within what degree of accuracy? As compared to what?"12

\section{DEVELOPING SPECIFIC MEASURES OF PERFORMANCE}

Establishing measures means that supervisors need to think about the work module for student assistants. This is important for all employees, but especially for students who work only a few hours per day and tend to be given re- 
petitive and routine tasks. The work module refers to the fact that student work should be planned so that it leads to successful task completion-successful for the student and for the library. Planning a work module means that the supervisor determines how long a student can do a task before beginning to commit errors.

For example, the supervisor of student employees responsible for accurately shelving books should look closely at the number of books that can be accurately shelved in his or her library and the number of hours a student employee can shelve books without a high error rate. If the supervisor determines that the average shelver can accurately shelve fifty books per hour and that two hours is the maximum time that a person can shelve without errors, then the performance measure for this work is defined as shelving 100 books in two hours. If the average book truck holds 150 books or twenty-five books per shelf, then it would be appropriate to load only four of the six shelves. This communicates the standard that is expected in a two-hour shift and gives the student employee a sense of accomplishment when the truck is empty. It is important that this type of standard be worked out for each individual library. The number of books that can be shelved depends on the size of the library, whether or not the books are presorted, and the size of the class range each shelver is expected to shelve.

Using a given job description, the immediate supervisor should develop performance measures for each responsibility. The individual or group of individuals currently doing the job can provide invaluable help in this process. The incumbent can verify that the responsibilities reflect what is currently being done and may have insight into how much can be done in the amount of time allotted. This also assures that measures will be equitable as well as efficient. It is important to remember that average performance is the expectation. The fact that the supervisor can do the task in 25 percent less time does not necessarily mean that that should constitute the standard. It may be impossible in the training process to provide the student employee with all of the information the supervisor has; thus the student employee may not have the knowledge necessary to perform the task as quickly as the supervisor. It is important to remember that, as Smith and Tucker pointed out, performance measures "do not define outstanding performance but rather identify a baseline for degrees of excellence and failure." ${ }^{13}$ This is why it is important to develop time data using a variety of people rather than figuring out how long it would take the supervisor to accomplish the task.

\section{Measuring the right things means that librarians are attentive to the results expected, not the task needed to attain the results. Shelving books is a task; shelving books in the correct order is a result.}

At the same time, the supervisor should look at the nature of the work module. Obviously a serials student assistant should not begin work before the mail is delivered and sorted. In addition, the supervisor should determine how much time it takes each day to complete the task. Is it necessary, for example, to have a longer work period on Monday than the other days of the week? For the sake of this example, we will assume that the responsibilities listed above can be accomplished in two hours per day Monday through Friday. Care should be taken to ensure that equitable measures are developed for jobs with varying work flows.

The first step in writing performance measures begins with the job description. It is essential that time measures be developed from job descriptions at each individual library. Although there are some suggestions in the literature on how long it should take to perform various tasks, the size of the library, division of labor, work flow, physical location, and the degree of accuracy needed can all have a dramatic effect on how long it takes to perform a specific task. Sam- 
pling the work being performed, time studies, and standard time data are fully covered in the book by Richard M. Dougherty and Fred J. Heinritz, Scientific Management of Library Operations, for those interested in investigating this further.14 The next step is to add up the time to see if the job can be done in the time available.

All performance measures should have the following characteristics: be based on an up-to-date job description; be focused on results, not activities; be realistic and reasonable; be observable and measurable; be controllable; and be understandable, not too wordy, and not too numerous.

\section{PERFORMANCE EXPECTATIONS}

The quantitative and qualitative performance measures or expectations for any student position could be summarized in a performance expectations worksheet such as the following:

\section{PERFORMANCE EXPECTATIONS WORKSHEET}

1. List three or four key activities of the job

2. List the key results or outcomes of these activities. (What are the results you want?)

3. List the behaviors or skills to be used in achieving the results. (How do you want the job done?)

4. Write the specific performance expectations, by combining numbers two and three above.

\section{EVALUATION}

If both the supervisor and the student employee have and understand both the job description and the performance expectations of a given position, then evaluation becomes easier. Both the quantity and quality of the work to be performed are clear and the evaluation process can revolve around the degree to which the student employee meets these clearly stated expectations. With performance measures in place, evaluation of student work can become an ongoing process rather than an end-of-the-year summation. Combining the use of performance measures with ongoing evaluation allows for a more productive work experience and prevents "problem workers." This focuses both the supervisor's and the student's attention on the results expected from a job.

\section{CONCLUSION}

Performance measures set our expectations for how student employees should perform in our libraries. Perfor-mance measures are important in identifying how much a given student can be expected to do. Even though each library needs to tailor performance measures to its unique situation, performance measures clearly assist in planning and monitoring student work. Standards can improve the students' commitment to their work along with their sense of accomplishment. Finally, performance measures are invaluable in the management of student employees, particularly in motivation and evaluation.

\section{REFERENCES}

1. Michael D. Kathman and Jane M. Kathman, CE 107: Managing Student Workers in Academic Libraries (Chicago: Assn. of College \& Research Libraries, 1983).

2. Michael D. Kathman and Jane M. Kathman, "Integrating Student Employees into the Management Structure of Academic Libraries," Catholic Library World 56:328-30 (Mar. 1985).

3. James Evered, "How to Write a Good Job Description," Supervisory Management 26:17 (Apr. 1981).

4. Richard M. Dougherty and Fred J. Heinritz, Scientific Management of Library Operations, 2d ed. (Metuchen, N.J.: Scarecrow, 1982), p.237.

5. Evered, "How to Write a Good Job Description," p.14.

6. Robert F. Smith and Kerry Tucker, "Measuring Individual Performance," Public Relations Journal 38:27 (Oct. 1982). 
7. Donald Shabel, "Performance Standards and Cost Analysis,"Illinois Librarian 64:875 (Spring 1982).

8. Mary Ann Joyce, "Developing and Negotiating Job Standards," The Bookmark 40:213 (Summer 1982).

9. Stanley P. Hodge, "Performance Appraisals: Developing a Sound Legal and Managerial System," College \& Research Libraries 44:240 (July 1983).

10. Evered, "How to Write a Good Job Description," p.16.

11. Ibid.

12. Smith and Tucker, "Measuring Individual Performance," p.27.

13. Ibid.

14. Dougherty and Heinritz, Scientific Management of Library, p.237.

\section{IN FORTHCOMING ISSUES OF COLLEGE \& RESEARCH LIBRARIES}

Journal Price Escalation and the Market for Information

Bruce R. Kingma and Philip B. Eppard

New Norms for Reference Desk Staffing Adequacy: A Comparative Study

Deborah Rinderknecht

Strategic Planning as a Catalyst for Change in the 1990s

Meredith Butler and Hiram Davis

College Libraries and Resource Sharing: Testing a Compact Disc Union Catalog for the Associated College Libraries of Central Pennsylvania Charles Townley

On Becoming Faculty Librarians: Acculturation Problems and Remedies W. Bede Mitchell and Bruce Morton

Research Notes

Conference Proceedings in Plysics

H. H. Barschall and W. Haeberli 


\section{Available}

Now From ACRL

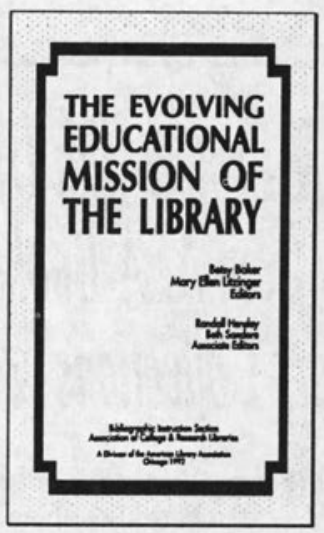

\& RESEARCH

LIBRARIES

Association OF

COLLEGE

\& RESEARCH

LIBRARIES

Association OF

COLLEGE

\section{The Evolving Educational Mission of the Library}

\& RESEARCH

\section{Betsy Baker and Mary Ellen Litzinger, Editors}

The Evolving Educational Mission of the Library provides a series of essays articulating ideas on information literacy in library user education, the information explosion impact on information organization and access in the curriculum, user demography creating new educational constituencies, and impact on changes in academic libraries on information science curricula.

While these essays were not explicitly prepared for the Bibliographic Instruction Section's Think Tank of June 22-23, 1989, they represent an articulation of ideas that had their genesis in those deliberations.

Academic librarians, library school educators, and higher education faculty and administrators will want this book.

$\$ 29.95$ ( $\$ 19.95$ for ACRL members) 202 pp, 1992, ISBN 0-8389-7584-4

Order Department ALA Publishing Services 50 East Huron Street Chicago, IL 60611
Or call toll-free 1-800-545-2433

Fax: 312-944-2641 


\section{Preserve \& Protect with Outstanding Preservation Guidelines from ALA Books and the Association for Library Collections \& Technical Services}

\section{Guide to the Library Binding Institute Standard for Library Binding Jan Merrill-OIdham and Paul Parisi}

The Guide, both a supplement and complement to the LBI Standard, translates the technical language of the Standard into usable information that will enable librarians to use it to its fullest advantage.

\$23.00pbk. 62p. ALA Order Code 3391-2-0011 1990

Guide to Review of Library Collections:

Preservation, Storage, and Withdrawal

Collection Management and Development Guides, \#5

Lenore Clark, editor

Designed to assist librarians and others who review materials in general collections for preservation, storage, and withdrawal. Based on review and study of the literature, examination of various existing policies, and contributions from professional colleagues.

\$7.00pbk. 41p. ALA Order Code 3396-3-0011 1991

\section{ALA Target Packet for Use in Preservation Microfilming Debra McKern and Sherry Byrne}

“... a necessary purchase for anyone involved in preservation microfilming ... joins the two or three other such titles that comprise the preservation microfilmer's basic bookshelf." Conservation Administration News

$\$ 32.00$ pbk. 60p. manual/18 Camera-ready cards 1991
ALA Order Code 7492-9-0011

\section{Preservation Microfilming: Planning \& Production}

Gay Walker, editor

Papers from the RTSD Preservation Microfilming Institute, New Haven, CT, April 21-23, 1988.

\$12.00pbk. 72p. ALA Order Code 7324-8-0011 1989

\section{A Core Collection in Preservation}

Lisa L. Fox

"an extremely useful and inexpensive bibliography [listing] works on applications of micrographics for library preservation as part of a holistic approach to the national preservation effort." Microfilm Review Quarterly

\$5.00pbk. 15p. ALA Order Code 7224-1-0011 1988

ALA Books - 50 East Huron Street - Chicago, IL 60611 1-800-545-2433; press 7 to order 